\title{
Distribution of Free D-Aspartic Acid and D-Aspartate Oxidase Activity in the Tissues of Octopus vulgaris
}

\author{
Eizo Nagahisa, ${ }^{* 1}$ Nobuhiro Kanno, ${ }^{* 1}$ Minoru Sato, ${ }^{* 2}$ and Yoshikazu Sato*1 \\ (Received May 17, 1993)
}

\begin{abstract}
The occurrence of free D-aspartic acid was measured in various tissues and organs of the octopus Octopus vulgaris by means of chiral HPLC amino acid analysis. This amino acid was detected in appreciable quantities in almost all of the tissues examined (muscle, renal appendage, ventricle, branchial heart, gill, crop, stomach, cecum, intestine, salivary gland, brain, and eye) except the hepatopancreas and gonad. In particular, the amount of D-aspartic acid in the intestine was 5- to 10 -fold that in other tissues. The ratios of $\mathrm{D} / \mathrm{L}$ were 2 or more in brain, eye, and intestine, but were less than 1 in the other tissues. D-Aspartate oxidase (EC 1.4.3.1) activity was found in various digestive organs and in the muscle of the octopus, but it was not detected in the brain, eye, gill, salivary gland, or gonad. The enzyme activity was highest in the cecum $(1.3 \mathrm{U} / \mathrm{g}$ tissue) and was relatively high in the renal appendage, hepatopancreas, and intestine $(0.8,0.6$ and $0.5 \mathrm{U} / \mathrm{g}$ tissue, respectively). The oxidizing activity towards $\mathrm{L}$-aspartic acid was only slightly detected in all of the tissues examined. These results imply that the D-aspartic acid in octopus tissues originates mainly from intestinal bacteria and feed, and that the D-aspartate oxidase secreted from the cecum controls the accumulation of this amino acid.
\end{abstract}

It has generally been observed that the proteins and free amino acid pools of almost all living organisms except some bacteria are composed of Lamino acids, thus $\mathrm{D}$-amino acids have been thought of as being unnatural. However, D-amino acids have been found either in the free form or combined with other molecules in several animals ${ }^{12}$ and plants. ${ }^{2,8}$

In recent years, the occurrence of D-aspartic acid and its biochemical and physiological role in mammals have gained increasing attendion in various research fields. Helfman and Bada ${ }^{4,5)}$ reported that $\mathrm{D}$-aspartic acid accumulates in human tooth enamel and dentine with aging, and similar results have been recognized in the human eye lens, ${ }^{8)}$ brain, ${ }^{7,8)}$ and aortic elastin. ${ }^{8)}$ D-Aspartic acid has also been identified as an important neurotransmitter in nervous tissue. ${ }^{102}$ Furthermore, there have been some discussions concerning Alzheimer's disease ${ }^{11-147}$ and lesions of the red nucleus in guinea pigs. ${ }^{15 \%}$ In addition, this amino acid was found in various tissues of rat, ${ }^{162}$ chicken embryo, ${ }^{17}$ ) mouse kidney, ${ }^{18}$ ) and amphibians. ${ }^{19)}$ Free D-aspartic acid has also been found in marine organisms, such as the nervous organs of cephalopods, ${ }^{20,21)}$ bivalves, ${ }^{22)}$ and some species of marine macroalgae. ${ }^{23)}$ However, the physiological function of D-aspartic acid in marine organisms is still unclear.

D-Aspartate oxidase (EC 1.4.3.1) is a peroxisomal flavoenzyme catalyzing the deaminative oxidation of dicarboxylic D-amino acids, and this enzyme activity was discovered in rabbit kidney in 1949 by Still $e t$ al. ${ }^{24}$ ) Since then, such enzyme activity has been found in octopus hepatopancreas, ${ }^{28)}$ various mammalian tissues, ${ }^{28)}$ and in amphibian tissues. ${ }^{\left.1{ }^{1}\right)}$ However, the physiological function of the enzyme remains uncertain.

In this paper, we report on the distribution of free D-aspartic acid and D-aspartate oxidase activity in the various tissues of Octopus vulgaris. Our findings differed in several respects from the results of the previous report. ${ }^{20}$

\section{Materials and Methods}

\section{Animals and Tissues}

Live specimens of Octopus vulgaris weighing 1$2 \mathrm{~kg}$ were obtained from a fisherman in Okirai Bay, Iwate Prefecture.

*1 School of Fisheries Sciences, Kitasato University, Sanriku, Iwate 022-01, Japan（長久英三，营野 传弘, 佐藤美和: 北里大学水産学部).

*2 Faculty of Agriculture, Tohoku University, Sendai 981, Japan (佐藤 奏: 東北大学朢学部). 
The muscle and various organs were rapidly dissected and rinsed with ice-cold water. The digestive organs, such as the stomach, crop, cecum, and intestine, were cut open and the inner matter was carefully washed away. Then these organs were kept frozen at $-20^{\circ} \mathrm{C}$ until analysis.

\section{Determination of $\mathrm{D}$-Aspartic Acid}

Homogenates were routinely prepared from 1 $5 \mathrm{~g}$ tissue with $3 \mathrm{vol}$. of $1 \mathrm{~N}$ perchloric acid. Homogenization was carried out at temperatures below $4^{\circ} \mathrm{C}$ for $10 \mathrm{~min}$, using an Ystral disperser. The supernatant obtained after centrifugation at $10,000 \mathrm{~g}$ for $20 \mathrm{~min}$ was neutralized with $10 \mathrm{~N}$ $\mathrm{KOH}$. After standing for 1 to 2 hours in the cold, the precipitate was removed by centrifugation at $8,000 \mathrm{~g}$ for $10 \mathrm{~min}$. The supernatant was evaporated to dryness under reduced pressure at 45 $50^{\circ} \mathrm{C}$ and the residue was dissolved in $15 \mathrm{ml}$ of distilled water. A $5 \mathrm{~m} l$ sample of the extract was loaded on a Dowex 1 (100-200 mesh, acetate form) column $(30 \mathrm{~m} /$ vol.). After the column had been washed with $500 \mathrm{~m} /$ of distilled water, adsorbed acidic amino acids were eluted with $500 \mathrm{~m} /$ of $4 \mathrm{~N}$ acetic acid. The eluate was evaporated to dryness under similar conditions to remove acetic acid and the residue was dissolved in $10 \mathrm{ml}$ of deionized water. This sample solution was analyzed by means of the chiral HPLC amino acid analysis described by Sato et al. ${ }^{27)}$ A Jasco model LC-800 HPLC system was used for measurement of $D$ aspartic acid, and fluorometric analysis was performed with an excitation wavelength of $348 \mathrm{~nm}$ and an emission wavelength of $450 \mathrm{~nm}$.

\section{Enzyme Assay}

Crude enzyme solution for the assay of D-aspartate oxidase activity was prepared by homogenizing each tissue with 3 vol. of $50 \mathrm{~mm}$ Tris- $\mathrm{HCl}$ buffer containing $2 \mathrm{~mm}$ EDTA, $1 \mathrm{~mm}$ 2-mercaptoethanol and $10 \mathrm{~mm}$ flabin adenine dinucleotide (FAD) $(\mathrm{pH} 8.0)$ and by centrifuging at $10,000 \mathrm{~g}$ for $30 \mathrm{~min}$ at $0^{\circ} \mathrm{C}$. The supernatant was dialyzed overnight against the same buffer with three changes to eliminate the endogenous amino acids and salts. The enzyme solution was stored at $0^{\circ} \mathrm{C}$ and used within several days.

The activities of D-aspartate oxidase and Damino acid oxidase were assayed according to the method of Watanabe et al. ${ }^{28)}$ except for the use of $30 \mu \mathrm{mol}$ (final concentration) D-aspartic acid or D-alanine as substrate.

One unit of these enzymes was defined as the amount of enzyme producing $1 \mu \mathrm{mol}$ of $\mathrm{H}_{2} \mathrm{O}_{2}$ per min at $40^{\circ} \mathrm{C}$ under the reaction conditions. The enzyme activity of the tissue was expressed in units per gram of fresh tissue.

\section{Results and Discussion}

Distribution of D-Aspartic Acid in Octopus Tissues

Concentrations of $\mathrm{D}$ - and L-aspartic acid were measured in 14 tissues of octopus and the inner matter of two digestive organs (stomach and intestine) by means of chiral HPLC amino acid analysis.

Figure 1 shows chromatograms of standard DLamino acids (Fig. 1A) and some samples, obtained by means of HPLC. The chromatogram of muscle extract showed three major peaks corresponding to D-, L-aspartic acids, and L-glutamic acid (Fig. 1B). That of the muscle extract hydrolyzed with $6 \mathrm{~N} \mathrm{HCl}$ at $110^{\circ} \mathrm{C}$ for 20 hours also showed a similar pattern with an unknown peak (Fig. 1C). The chromatogram of brain extract showed four major peaks corresponding to $D$-, $L$-aspartic acids and D-, L-glutamic acids (Fig. 1D). Similar results were obtained in other tissues extracts (data not shown), but no D-glutamic acid peak was detected except in the brain extract. A large part of the D-aspartic acid probably occurs in a free form in octopus tissues. The distribution of Daspartic acid in the tissues of octopus is summarized in Table 1. D-Aspartic acid was detected in almost all of the tissues examined, but not clearly in the gonad or hepatopancreas. Comparable levels of $\mathrm{D}$-aspartic acid concentration (3$9 \mu \mathrm{mol} / \mathrm{g}$ fresh tissue) were found in muscle, brain, eye, and almost all digestive organs except the intestine, where a significantly high concentration ( $50 \mu \mathrm{mol} / \mathrm{g}$ tissue) of it was detected. D'Aniello and Giuditta ${ }^{20,212}$ searched for D-amino acids in the organs of cephalopods by means of an assay method based on the use of specific oxidase and reported that D-aspartic acid was present in thier nervous system ( $2-15 \mu \mathrm{mol} / \mathrm{g}$ fresh tissue) but not in non-nervous organs. The disparity in results may be due to the use of different assay methods.

The concentration of D-aspartic acid in octopus tissues was significantly higher than that in various tissues of rats ${ }^{16)}$ and chicken embryo, ${ }^{17)}$ in mouse kidney (mutant strain lacking D-amino acid oxidase and its control strain), ${ }^{18)}$ in human brain (normal and Alzheimer) ${ }^{11-14)}$ and in kidney and liver of amphibians, ${ }^{12)}$ whereas it was of a similar level in several marine bivalves.22) The ratios of 


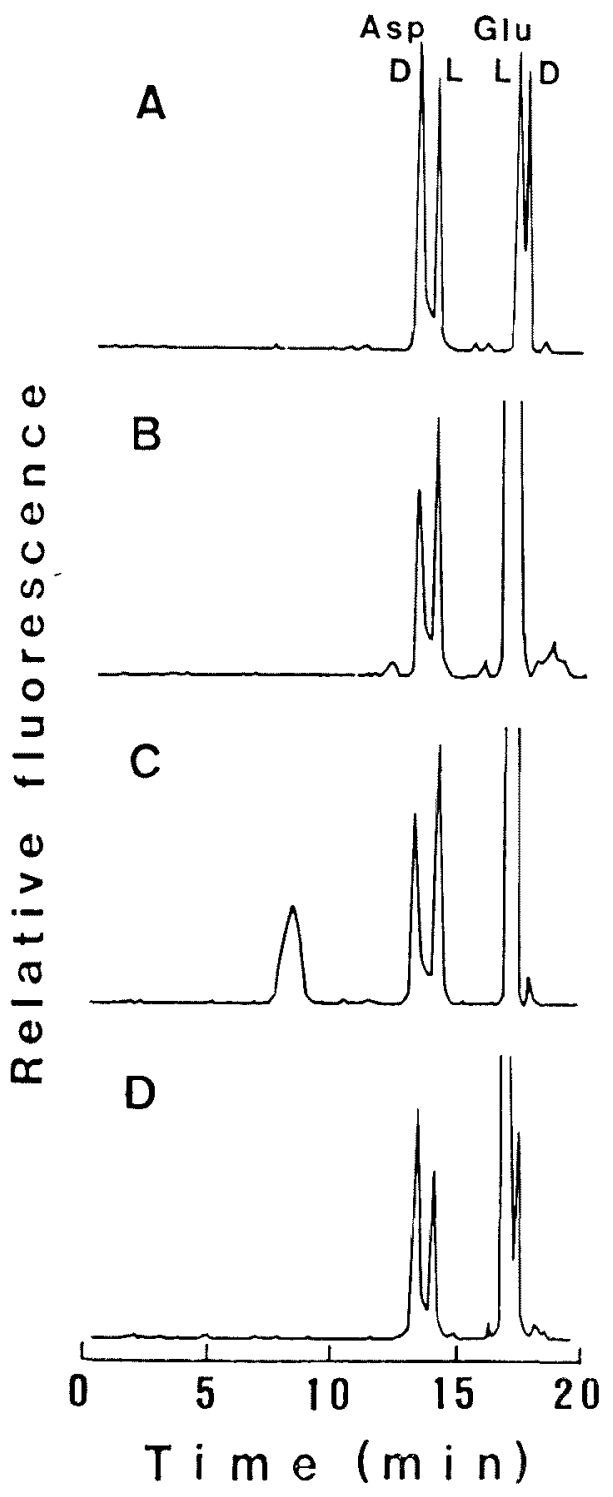

Fig. 1. Chromatograms of OPA-NAC derivatives of standard DL-amino acid and extracts of octopus tissues.

A: standard DL-aspartic acid and DL-glutamic acid, B: muscle extract, $C$ : hydrolyzed muscle extract with $\mathrm{HCl}, \mathrm{D}$ : brain extract.

Reversed-phase HPLC was performed on a column $(250 \times 4.6 \mathrm{~mm})$ of TSK-ODS $80 \mathrm{~T}(5 \mu \mathrm{m}$ particle size) at $40^{\circ} \mathrm{C}$. Materials were eluted from the column with the mixture of solvent A $(50 \mathrm{~mm}$ sodium acetate buffer, $\mathrm{pH} 5.4)$ and solvent B (acetonitrile). The gradient was set as follows: $0-10 \mathrm{~min}, 0-10 \%$ solvent $B$ in solvent $\mathrm{A} ; 10-20 \mathrm{~min}, 10 \%$ solvent $\mathrm{B}$ in solvent
Table 1. Distribution of D-aspartic acid in the tissues of Octopus vulgaris

\begin{tabular}{lcc}
\multicolumn{1}{c}{ Tissue } & $\begin{array}{c}\text { D-Asp } \\
(\mu \mathrm{mol} / \mathrm{g} \text { tissue })\end{array}$ & $\begin{array}{c}\text { D/L } \\
\text { ratio }\end{array}$ \\
\hline Muscle (arm) & $5.7 \pm 2.8$ & 0.9 \\
Brain* $_{\text {Eye* }}^{*}$ & $4.8 \pm 1.4$ & 2.0 \\
Ventricle & $4.9 \pm 1.7$ & 1.9 \\
Branchial heart & $2.7 \pm 0.6$ & 0.4 \\
Gill & $2.9 \pm 1.0$ & 0.1 \\
Gonad & $3.2 \pm 0.9$ & 0.4 \\
Salivary gland & $\mathrm{ND}$ & - \\
Crop & $3.2 \pm 2.5$ & 0.1 \\
Stomach & $6.1 \pm 2.7$ & 0.7 \\
Content of the stomach* & $3.8 \pm 1.8$ & 0.3 \\
Cecum & $6.8 \pm 2.2$ & 0.5 \\
Intestine & $8.5 \pm 0.9$ & 0.1 \\
Content of the intestine* & $51.2 \pm 4.9$ & 2.5 \\
Hepatopancreas & $5.2 \pm 1.6$ & 0.5 \\
Renal appendage & $\operatorname{Tr}^{3)}$ & - \\
\hline
\end{tabular}

1) Values are means $\pm \mathrm{SD}$ obtained from two $\left({ }^{*}\right)$ or four specimens.

2) Not detected.

3) Below the level of $1.0 \mu \mathrm{mol} / \mathrm{g}$ wet tissue.

Table 2. D-Aspartate oxidase activity in the tissues of Octopus vulgaris

\begin{tabular}{lc}
\hline \multicolumn{1}{c}{ Tissue } & $\begin{array}{c}\text { DAO activity } \\
\text { (Unit/g tissue) }\end{array}$ \\
\hline Muscle (arm) & 0.08 \\
Brain* $^{*}$ & ND ${ }^{2}$ \\
Eye* $^{*}$ & ND \\
Ventricle & 0.24 \\
Branchial heart & 0.09 \\
Gill & ND \\
Gonad & ND \\
Salivary gland & ND \\
Crop & 0.16 \\
Stomach & 0.10 \\
Cecum & 1.29 \\
Intestine & 0.52 \\
Hepatopancreas & 0.60 \\
Renal appendage & 0.84
\end{tabular}

i) Values are measns obtained from one (*) or three specimens. 2) Not detected.

A. The flow rate was $1.0 \mathrm{~m} / / \mathrm{min}$ throughout. Fluorometric detection was performed with an excitation wavelength of $348 \mathrm{~nm}$ and an emission wavelength of $450 \mathrm{~nm}$. An amount of 45.5 pmol of standard amino acids was injected. The extracts from octopus tissues were hydrolyzed with $6 \mathrm{~N} \mathrm{HCl}$ at $110^{\circ} \mathrm{C}$ for 20 hours. 
Table 3. Oxidizing activity towards various substrates in tissues of Octopus yulgaris

\begin{tabular}{|c|c|c|c|c|c|c|}
\hline \multirow{2}{*}{ Tissue } & \multicolumn{6}{|c|}{ Activity $^{1}$ (U/g tissue) } \\
\hline & D-Asp. & L-Asp. & D-Glu. & L-Glu. & D-Ala. & L-Ala. \\
\hline Cecum & 1.29 & - & 1.97 & - & 0.15 & - \\
\hline Intestine & 0.52 & - & 0.81 & - & $\operatorname{Tr}^{33}$ & - \\
\hline Hepatopancreas & 0.60 & - & 0.58 & - & $\operatorname{Tr}$ & - \\
\hline Renal appendage & 0.84 & - & 0.88 & - & 0.80 & - \\
\hline
\end{tabular}

D-aspartic acid to its $L$-form in octopus tissues were less than 1 in many tissues examined, but were about 2 or more in brain, eye, and intestine.

D-Aspartic acid was also detected in the inner matter of stomach and intestine of octopus (Table 1). The inner matter consisted mainly of sardines given to the octopus as fishing bait; however, Daspartic acid was only slightly detected in whole sardine extract (below $0.1 \mu \mathrm{mol} / \mathrm{g}$ sample). On the other hand, some marine bivalves and crustaceans which are feed for the octopus also contained D-aspartic acid (1-10 $\mu \mathrm{mol} / \mathrm{g}$, unpublished). These results suggest that at least a part of the Daspartic acid in the octopus tissues originates from intestinal bacteria and feed. By contrast, Nagata and Akino $^{29}$ ) reported that D-amino acids in mouse tissues were not of microbial origin since these amino acid concentrations did not differ between germ-free mice and specific pathogenfree mice. In addition, Matsushima et al. ${ }^{30\rangle}$ suggested that $\mathrm{D}$-alanine in a species of bivalve was dependent on the alanine racemase of the bivalve tissues. The presence of aspartate racemase in octopus tissues is still doubtful.

\section{D-Aspartate Oxidase Activity in Octopus Tissues}

D-Aspartate oxidase activity was detected in muscle, ventricle, branchial heart, crop, stomach, cecum, intestine, hepatopancreas, and renal appendage, but not in brain, eye, gill, gonad, or salivary gland (Table 2). Enzyme activity was highest in the cecum $(1.3 \mathrm{U} / \mathrm{g}$ tissue) and was relatively high in renal appendage $(0.8 \mathrm{U} / \mathrm{g})$, hepatopancreas $(0.6 \mathrm{U} / \mathrm{g})$, and intestine $(0.5 \mathrm{U} / \mathrm{g})$, but in other tissues and organs it was only about onefifth to one-tenth of that in the cecum. In mammals, D-aspartate oxidase activity is high in the kidney and liver, ${ }^{20}$ whereas the activity in octopus was significantly high in the cecum. In octopus, additionally, the lack of D-aspartate oxidase was observed in the brain, which is one of its main sources in mammals. This finding agreed with the results of D'Aniello and Giuditta. ${ }^{28)}$ Thus, the distribution of $\mathrm{D}$-aspartate oxidase activity in octopus tissues differed from that in mammals.

The oxidizing activities of the extracts of cecum, hepatopancreas, and renal appendage in octopus towards some substrates were determined (Table 3). These tissue extracts showed apparently higher activity towards D-glutamic acid than towards D-aspartic acid (Table 3). According to Hamilton, ${ }^{2 B}$ D-aspartic acid is generally the best substrate for the mammalian enzyme with the reaction rate of $\mathrm{D}$-glutamic acid at approximately one-tenth that of D-aspartic acid. Furthermore, in amphibian liver, it has been reported that the oxidizing activity towards D-glutamic acid was $15-33 \%$ of that towards D-aspartic acid. ${ }^{10)}$ Thus, it is probable that the substrate specificity of $D$ aspartate oxidase varies according to the animal. On the other hand, oxidizing activity towards Dalanine was also observed in the extracts of cecum and renal appendage of octopus, but slight activity towards L-amino acids such as L-aspartic acid, glutamic acid, and alanine was found in all of the tissues examined.

The physiological role of D-aspartic acid and D-aspartate oxidase in organisms is still unclear. There are some reports that D-aspartic acid accumulates in human tissues with aging and senescence. ${ }^{4-\theta)}$ Shapira et al. ${ }^{11}$ and Fisher et $a l^{12-14}$ suggested that D-aspartic acid in the human brain is related to Alzheimer's disease. On the other hand, in marine organisms, D'Aniello and Giuditta $^{20,21)}$ suggested that this amino acid might have a specific neural function, and Nagahisa et al. ${ }^{23)}$ suggested that D-aspartic acid might be involved in the sporulation of marine macroalgae. In this work, it seems likely that at least some of the D-aspartic acid in octopus tissues originated from intestinal bacteria and feed, but its physiological function was not clear. Hamilton ${ }^{282}$ has sug- 
gested that there was some other physiological substrate for the enzyme because D-aspartic acid did not generally seem to be toxic to animals.

The possible presence of D-aspartic acid in marine organisms and its involvement in metabolism should not be overlooked.

\section{Ackowledgments}

We would like to express our special thanks to The Central Research Laboratory of Nippon Suisan Kaisha Ltd. for supporting this work. We would also like to express our thanks to $\mathrm{Mr}$. N. Kawahata, a fisherman in Okirai Bay, for providing valuable samples of octopus.

\section{References}

1) J. J. Corrigan: D-Amino acids in animals. Science 164, 142-149 (1969).

2) T. Ogawa, M. Kimoto, and K. Sasaoka: Identification of D-aspartic acid and D-glutamic acid in pea seedlings. Agric, Biol. Chem., 41, 1811-1812 (1977).

3) S. Hunt: Chemistry and Biochemistry of the Amino Acid (ed. by Barrett, G. C.), Chapman and Hall, New York, 1985, pp. 55-138.

4) P. M. Helfman and J. L. Bada: Aspartic acid racemization in tooth enamel from living humans. Proc. Natl. Acad. Sct. USA, 72, 2891-2894 (1975).

5) P. M. Helfman and J. L. Bada: Aspartic acid racemization in dentine as a measure of aging. Nature, 262, 279-281 (1976).

6) P. M. Masters, J. L. Bada, and J. S. Jr. Zigler: Aspartic acid racemization in human lens during aging and in cataract formation. Nature, 268, 71-73 (1977).

7) E. H. Man, M. E. Sandhouse, J. Burg, and G. H. Fisher: Accumulation of D-aspartic acid with age in the human brain. Science, 220, 1407-1408 (1983).

8) E. H. Man, G. H. Fisher, I. I. Payan, R. Cadilla-Perezrios, N. M. Garcia, R. Chemburkar, G. Arends, and W. H. Frey I1: D-Aspartate in human brain. J. Neurochem., 48, 510515 (1987).

9) J. J. Powell, N. Vine, and M. Crosssman: On the accumuIation of $\mathrm{D}$-aspartate in elastin and other proteins of the aging aorta. Atherosclerosis, 97, 201-208 (1992).

10) L. Wiklund, G. Toggenburger, and M. Cuenod: Aspartate Possible neurotransmitter in cerebellar climbing fibers. Science, 216, 78-80 (1982).

11) R. Shapira, G. E. Austin, and S.S. Mirra: Neuritic plaque amyloid in Alzheimer's disease is highly racemized. $I$ Neurochem, 50, 69-74 (1988).

12) G. H. Fisher, A. D'Aniello, L. Padula, G. P. Cusano, and E. H. Man: Free D-aspartate and D-alanine in normal and A zheimer brain. Brain Res. Bull, 26, 983-985 (1991).
13) G. H. Fisher, I. L. Payan, S-J. Chou, E. H. Man, S. Cerwinski, T. Martin, C. Emory, and W. H. Frey, II: Racemized Daspartate in Alzheimer neurofibrillary tangles. Brain Res. Bull., 28, 127-131 (1992).

14) G. H. Fisher, A. D'Aniello, A. Vetere, G. P. Cusano, M. Chaver, and L. Petrucelli: Quantification of D-aspartate in normal and Alzheimer brains. Neuroscience Letters, 143, 215-218 (1992).

15) C. G. Benson, M. C. Chase, and S. J. Potashner: Decreased release of $D$-aspartate in the guinea pig spinal cord after lesions of the red nucleus. J. Neurochem., 56, 1174-1183 (1991).

16) D. S. Dunlop, A. Neidle, D. McHale, D. M. Dunlop, and A. Lajtha: The presence of free $D$-aspartic acid in rodents and man. Biochem. Biophys. Res. Commun., 141, 27-32 (1986).

17) A. Neidle and D.S. Dunlop: Developmental changes in free D-aspartic acid in the chicken embryo and in the neonatal rat. Life Sci., 46, 1517-1522 (1990).

18) H. Nagasaki, R. Yamada, R. Konno, Y. Yasumura, and A. Iwashita: D-Aspartate oxidase activity and D-aspartate content in a mutant mouse strain lacking D-amino acid oxidase. Experientia, 46, 468-470 (1990).

19) Y. Kera, H. Nagasaki, A. Iwashita, and R. Yamada: Presence of $\mathrm{D}$-aspartate oxidase and free $\mathrm{D}$-aspartate in amphibian (Yenopus laevis, Cynops pyrrhogaster). Comp. Biochem. Physiol, 103B, 345-348 (1992).

20) A. D'Aniello and A. Giuditta: Identification of D-aspartic acid in the brain of Octopus vulgaris Lam. J. Neurochem. 29, 1053-1057 (1977).

21) A. D'Aniello and A. Giuditta: Presence of D-aspartate in squid axoplasm and in other regions of the cephalopod nervous system. J. Neurochem., 31, 1107-1108 (1978).

22) H. Felbeck and S. Wiley: Free D-amino acids in the tissues of marine bivalves. Biol. Bull, 173, 252-259 (1987).

23) E. Nagahisa, N. Kanno, M. Sato, and Y. Sato: Occurrence of free D-aspartic acid in marine macroalgae. Biochem. Int. 28, 11-19 (1992)

24) J. L. Still, M. V. Buell, W. E. Knox, and D. E. Green: Studies on the cyclophorase system-VII. D-Aspartic oxidase. $J$, Biol. Chem., 179, 831-837 (1949).

25) A. D'Aniello and E. Rocca: D-Aspartate oxidase from the hepatopancreas of Octopus vulgaris Lam. Comp. Biochem. Physiol., 41B, 625-633 (1972).

26) G. A. Hamilton: Peroxisomal oxidases and suggestions for the mechanism of action of insulin and other hormones. Adv. Enzymol., 57, 85-178 (1985).

27) M. Sato, T. Yamaguchi, N. Kanno, and Y. Sato: Confirmation of D-aspartic acid in the novel dipeptide $\beta$-aspartylglycine isolated from tissue extract of Aplysia kurodai. Biochem. $J$., $263,617-620$ (1987)

28) T. Watanabe and T. Suga: A new colorimetric determina. tion of D-amino acíd oxidase and urate oxidase actiyity. FEBS Lett, 124, 159-162 (1981).

29) Y. Nagata and T. Akino: D-Amino acids in mouse tissues are not of microbial origin. Experientia, 46, 466-468 (1990).

30) O. Matsushima, H. Katayama, K. Yamada, and Y. Kado: Occurrence of free D-alanine and alanine recemase activity in bivalve molluses with special reference to intraceliular osmoregulation. Marine Biol. Lett., 5, 217-225 (1984). 